\title{
Freezing Tolerance and Nonstructural Carbohydrate Composition of Carpetgrass (Axonopus affinis Chase)
}

\author{
Edward Bush ${ }^{1}$, Paul Wilson ${ }^{2}$, Dennis Shepard ${ }^{3}$, and James McCrimmon ${ }^{4}$ \\ Department of Horticulture, Louisiana State University Agricultural Center, \\ 137 J.C. Miller Hall, Baton Rouge, LA 70803-2120 \\ Additional index words. Cold tolerance, winter kill
}

\begin{abstract}
An experiment to determine the nonstructural carbohydrate composition and nodal survival $\left(\mathrm{LT}_{50}\right)$ of common carpetgrass was conducted between 1993 and 1994 at Baton Rouge, La. Nonstructural carbohydrates in stolons were primarily sucrose [70-130 $\mathbf{m g} \cdot \mathrm{g}^{-1}$ dry weight $\left.(\mathrm{DW})\right]$ and $\operatorname{starch}\left(8-33 \mathrm{mg} \cdot \mathrm{g}^{-1} \mathrm{DW}\right)$. Total nonstructural carbohydrate (TNC) composition of stolons ranged between 30 to $165 \mathrm{mg} \cdot \mathrm{g}^{-1} \mathrm{DW}$. Node survival following exposure to $2{ }^{\circ} \mathrm{C}$ ranged from $0 \%$ in August-sampled grass to $48 \%$ in December. The $\mathrm{LT}_{50}$ following acclimation under field conditions was -2 to $-4{ }^{\circ} \mathrm{C}$. Environmental factors influenced nonstructural carbohydrate composition, partitioning, and node survival. No relationship between TNC concentration and low-temperature tolerance was found. This research confirms previous reports that low-temperature tolerance of carpetgrass is very poor, and its culture may be limited to geographical areas having moderate winter temperatures.
\end{abstract}

Cold hardiness is a major limiting factor for the survival of most warm-season turfgrasses. Adaptation zones for bermudagrass [Cynodon dactylon (L.) Pers.], centipedegrass [Eremochloa ophiuroides (Munro.) Hack.], St. Augustinegrass [Stenotaphrum secundatum (Waltz.) Kuntze], and common carpetgrass range from the transitional zone to the southern coastal states, where temperatures $\leq-18$ ${ }^{\circ} \mathrm{C}$ are infrequent. Carpetgrass is a low-maintenance, stoloniferous lawngrass grown in the southern Gulf Coast region of the United States (McCarty et al., 1992). The low-temperature tolerance $\left(\mathrm{LT}_{50}\right)$ of common carpetgrass has been reported to be very low; however, no quantitative research has been conducted (Beard, 1973).

Low-temperature acclimation, environmental conditions, species, and cultural practices have been associated with turfgrass cold hardiness (Beard, 1973). Acclimation of warmseason grasses begins as night temperatures approach $10{ }^{\circ} \mathrm{C}$ (West, 1973). Growth slows and photosynthetic rates decrease, with subsequent loss of chlorophyll. Carbohydrates are

Received for publication 10 July 1998 . Accepted for publication $16 \mathrm{Feb}$. 1999. Approved for publication by the director of the Louisiana Agricultural Experiment Station as manuscript number 98-28-0189. This research was supported by funds from state and matching funds allocated to the Louisiana State Univ. Agricultural Center. The cost of publishing this paper was defrayed in part by the payment of page charges. Under postal regulations, this paper therefore must be hereby marked advertisement solely to indicate this fact.

${ }^{1}$ Assistant Professor; to whom reprint requests should be addressed (e-mail: ebush@agctr.lsu.edu).

${ }^{2}$ Professor (e-mail: pwilson@agctr.lsu.edu).

${ }^{3}$ Former Assistant Professor. Present address: Novartis Crop Protection Inc., 11561 Hemlock Drive, Overland Park, KS 66210.

${ }^{4}$ Associate Professor. stored during the winter acclimation process (Ito et al., 1985). A positive correlation ( $\mathrm{r}=$ 0.78 ) was observed between sucrose concentrations and freezing tolerance of acclimated centipedegrass stolons (Fry et al., 1993). Levels of nonstructural carbohydrates have been correlated with cold tolerance of warm-season grasses. Acclimated bermudagrass had high protein levels, which may have contributed to an $\mathrm{LT}_{50}$ as much as $5^{\circ} \mathrm{C}$ lower than that of nonacclimated turf (Gatschet et al., 1994).

The hardiness of centipedegrass, bahiagrass (Paspalum notatum Flugge.), and St. Augustinegrass are very limited (Beard, 1973). Bermudagrass and zoysiagrass (Zoysia japonica Stead.) have poor and medium lowtemperature hardiness, respectively. The $\mathrm{LT}_{50}$ of centipedegrass was estimated at -7 to $-9^{\circ} \mathrm{C}$, with total nonstructural carbohydrate (TNC) concentrations of 170 to $200 \mathrm{mg} \cdot \mathrm{g}^{-1}$. St. Augustinegrass survived -5 to $-6{ }^{\circ} \mathrm{C}$ without significant damage in Louisiana (Fry et al., 1991); however, at lower temperatures significant damage was observed (Maier et al., 1994a; Robbins and Pharr, 1988). In contrast, 'Meyer' zoysiagrass is seldom damaged by low temperatures, and Rogers et al. (1975) determined that $\mathrm{LT}_{50}$ values $\left(-10\right.$ to $\left.-12{ }^{\circ} \mathrm{C}\right)$ were associated with the accumulation of nonstructural carbohydrates during fall acclimation.

The objective of our research was to determine the $\mathrm{LT}_{50}$ and the changes in nonstructural carbohydrate composition between August and March.

\section{Materials and Methods}

Common carpetgrass plots were fertilized with $49 \mathrm{~kg} \cdot \mathrm{ha}^{-1} \mathrm{~N}$ on $15 \mathrm{Apr}$. and $15 \mathrm{June} 1993$, mowed weekly at $5.0 \mathrm{~cm}$, and irrigated during drought stress at the Burden Research Plantation, Baton Rouge, La. Minimum and maximum temperatures were recorded daily (Fig. 1).

Grass plugs were harvested for tissue analysis and stolon node survival studies on 26 Aug., 23 Sept., 21 Oct., 12 Nov., and 16 Dec. 1993 and on 13 Jan., 10 Feb., and 8 Mar. 1994. Six grass plugs $10 \mathrm{~cm}$ in diameter were randomly harvested from each plot monthly, washed, and divided into leaves, stolons, and roots. Nonstructural (starch, sucrose, glucose, fructose) carbohydrate analyses were performed using the procedures described by Fry et al. (1993). Sugars were identified and quantified using high-performance liquid chromatography (HPLC) with a Bio-Rad column (BioRad, Richmond, Calif.). Starch concentrations were determined enzymatically by detecting released glucose using a Lambda 4 spectrophotometer (Perkin-Elmer Corp., Oak Brook, Ill.) (Fry et al., 1993). The summation of glucose and fructose levels is reported as reducing sugars in this paper.

Node survival of common carpetgrass was performed by harvesting, washing, and then exposing stolons to $1^{\circ} \mathrm{C}$ overnight in a low- 
temperature incubator (C1213; Curtis Matheson, Scientific, Houston). One-node cuttings were individually wrapped in moistened paper towels. Ten individually wrapped nodes were placed in a test tube for each of the temperature treatments $(1,0,-2,-4,-6$, or -8 ${ }^{\circ} \mathrm{C}$ ) with four replications. A chip of ice was placed into each test tube to encourage ice nucleation and reduce tissue supercooling. Additional stolons with inserted platinum probes were placed randomly in test tubes to monitor stolon tissue temperature. All test tubes were submerged in a 1 ethylene glycol : 1 water bath (model RM 20; Brinkman Instruments, Westbury, N.Y.) and bath temperatures was reduced $2{ }^{\circ} \mathrm{C} / \mathrm{h}$. Nodes remained at respective temperature treatments for $1 \mathrm{~h}$, and were thawed at $1{ }^{\circ} \mathrm{C}$ overnight. Nodes were unwrapped, placed in labeled petri dishes lined with moistened filter paper and maintained at $28{ }^{\circ} \mathrm{C}$ under grow lamps $\left(19 \mu \mathrm{mol} \cdot \mathrm{s}^{-1} \cdot \mathrm{m}^{-2}\right)$. The petri dishes were arranged in a randomized block design. If a shoot emerged from a node after 6 weeks, it was considered to have survived. Node survival is presented as a percentage of the $1^{\circ} \mathrm{C}$ control.

Analysis of variance was used to determine the significance of time of sampling on leaf, root, and stolon nonstructural carbohydrate composition, and on node survival for each sampling month independently, using the general linear model procedure (SAS Institute, 1991).

Mean separation by least square differences (LSD) at $P \leq 0.05$ was performed within each month (SAS Institute, 1991).

\section{Results and Discussion}

Carbohydrate content. The main nonstructural carbohydrates present were starch, sucrose, and reducing sugars (Figs. 2 and 3). Root and stolon tissues contained only low levels of reducing sugars. Starch levels were similar in all tissues. Concentrations of sucrose, reducing sugars, and TNC were consistently lower in roots than in leaves and stolons, except from January through March, when reducing sugars were not detected in stolon tissue.

Leaf starch content increased gradually from September to January, then rapidly in February and March (Fig. 2). West (1973) reported that starch accumulates in leaf chloroplasts of a grass plant subjected to $10{ }^{\circ} \mathrm{C}$ night temperatures. The rapid starch increases in February and March could be attributed to spring transition. Sucrose levels rose in a similar fashion, but at a much higher rate, from September through December. The level remained unchanged through February, and decreased slightly in March. The concentrations of reducing sugars increased from September to November, and again in February and March (Fig. 3). Total nonstuctural carbohydrate content rose continuously from September through January, paralleling the rate for sucrose. Rogers et al. (1975) suggested that declining temperatures decrease respiration, resulting in the accumulation of export sugars.

Root starch content fluctuated between

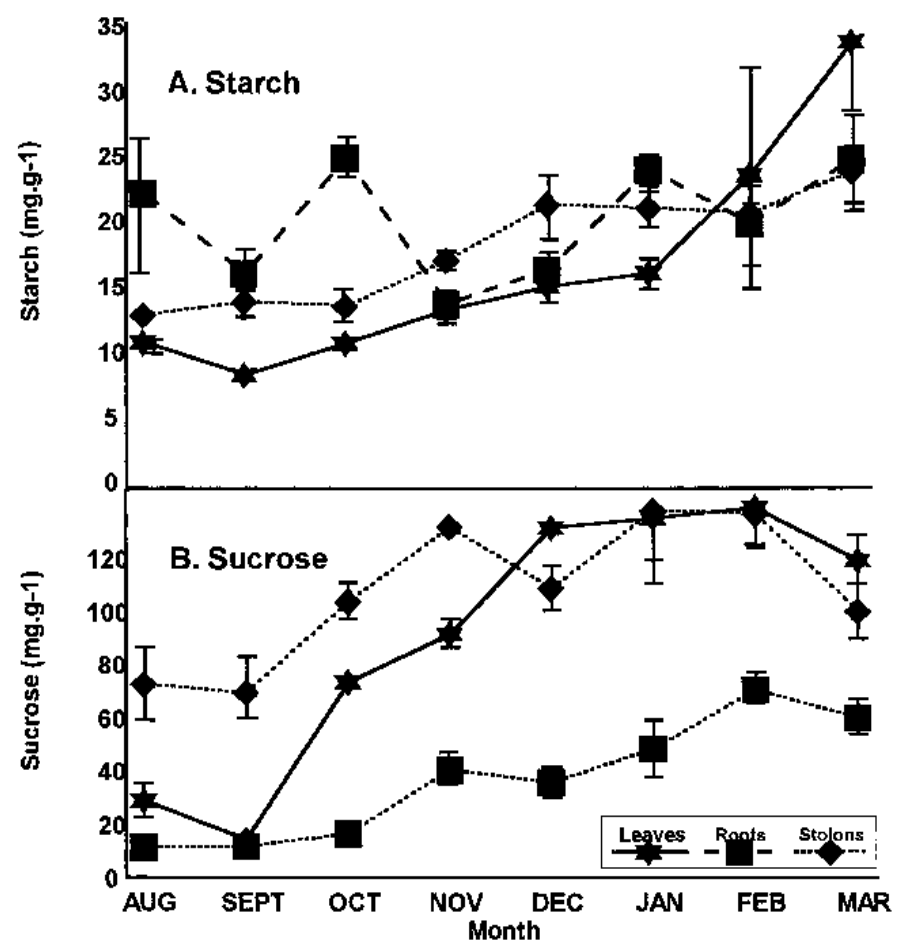

Fig. 2. Concentrations of (A) starch and (B) sucrose in leaves, roots, and stolons of common carpetgrass from Aug. 1993 to Mar. 1994. Vertical bars indicate SE for the mean of four replicate samples. No bar indicates that SE was smaller than the diameter of the symbol.

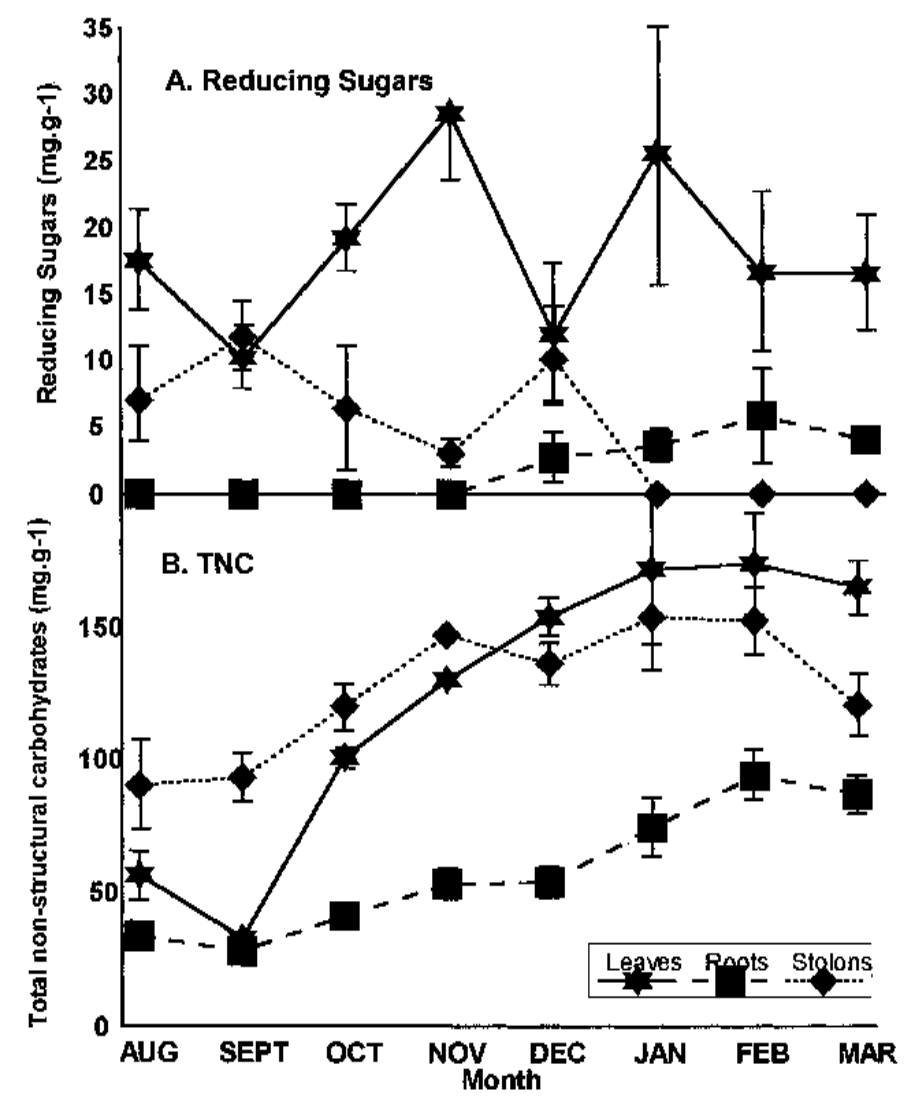

Fig. 3. Concentrations of (A) reducing sugars and (B) TNC in leaves, roots, and stolons common carpetgrass from Aug. 1993 to Mar. 1994. Vertical bars indicate SE for the mean of four replicate samples. No bar indicates that SE was smaller than the diameter of the symbol. 
August and November, then stabilized (Fig. 2 ). The concentration of sucrose rose slowly between August and February, then plateaued. Reducing sugars level was not detectable until December, then rose slowly until February and was stable in March (Fig. 3). Content of TNC rose gradually between August and February, then stabilized.

Stolon starch content changed little from August through October, then rose until December; little change occurred thereafter (Fig. 2). Sucrose levels rose from September through November, remained relatively high through February, then fell in March. Levels of reducing sugars declined from September through October, and rose in December (Fig. 3); concentrations were too low to be detectable thereafter. Concentrations of reducing sugars were similar to those reported in St. Augustinegrass (Fry et al., 1991). A gradual rise in TNC was observed from August until November. Levels remained relatively constant through February, then declined in March with the resumption of vegetative growth. Total nonstructural carbohydrate composition (90-148 $\mathrm{mg} \cdot \mathrm{g}^{-1}$ dry weight) in stolons was similar to that reported for St. Augustinegrass (Fry et al., 1991).

Survival. Node survival was relatively high in August at 0 and $-2{ }^{\circ} \mathrm{C}$, decreased slightly in September, but fluctuated thereafter (Fig. 4). Maximum hardiness occurred in November and December. Survival at $-4{ }^{\circ} \mathrm{C}$ was $<20 \%$ from August through November. Daily temperature fluctuations exceeding $20^{\circ} \mathrm{C}$ in late November and early January may have caused deacclimation of stolons (Fig. 1). Johnston and Dickens (1977) reported a loss in cold tolerance in centipedegrass in the lower south due to fluctuating warm temperatures in winter. The ability of warm-season grasses to remain physiologically dormant in the deep south is essential for surviving low temperatures. In both St. Augustinegrass and centipedegrass, growth in response to warming temperatures increases winter damage (Johnston and Dickens, 1977; Reeves and McBee, 1972).

Maximum survival occurred in December and February before sharply decreasing in March. Nodes did not survive exposure to -6 and $-8{ }^{\circ} \mathrm{C}$ in any month.

Relationships between carbohydrate levels and survival. Previous research has shown that accumulation of soluble carbohydrates, polyols, and water-soluble proteins increases freezing tolerance (Larcher, 1995). Stolons

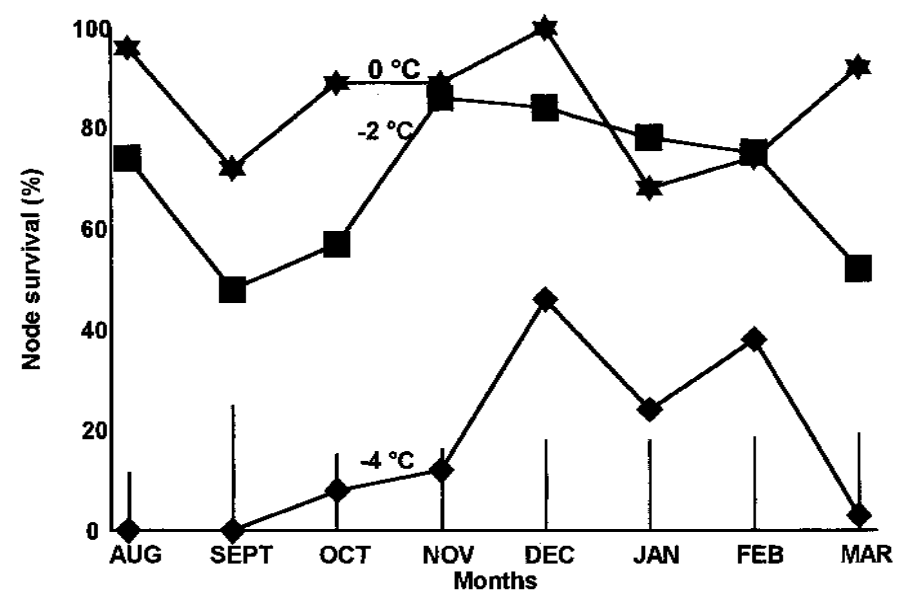

Fig. 4. Common carpetgrass node survival after $1 \mathrm{~h}$ of exposure to freezing temperatures in a 1 ethylene glycol: 1 water bath. Vertical bars represent LSD at $P \leq 0.05$ for each sampling date.

are important storage organs for carbohydrates during the fall hardening period (Dunn and Nelson, 1974). However, in our analyses, correlation coefficients between individual carbohydrate levels and survival revealed no good relationships between leaf, root, and stolon carbohydrate concentrations and node survival.

Maier et al. (1994b) also could not establish a relationship between nonstructural carbohydrates and low-temperature survival of St. Augustinegrass. Although we found no relationship between winter exposure and freezing tolerance, nonstructural carbohydrate composition of common carpetgrass leaves, roots, and stolons was established. Our data therefore establish a baseline for future study.

\section{Literature Cited}

Beard. J.B. 1973. Turfgrass science and culture Prentice-Hall, Englewood Cliffs, N.J.

Dunn, J.H. and C.J. Nelson. 1974. Chemical changes occurring in three bermudagrass turf cultivars in relation to cold hardiness. Agron. J. 66:28-31.

Fry, J.D., S.N. Lang, and R. Clifton. 1991. Freezing resistance and carbohydrate composition of 'Floratam' St. Augustinegrass. HortScience 26:1537-1539.

Fry, J.D., S.N. Lang, R. Clifton, and F.P. Maier. 1993. Freezing tolerance and carbohydrate content of low temperature-acclimated and nonacclimated centipedegrass. Crop Sci. 33:10511055.

Gatschet, M.J., C.M. Taliaferro, J.A. Anderson, D.R. Porter, and M.A. Anderson. 1994. Cold acclimation and alterations in protein synthesis in bermudagrass. J. Amer. Soc. Hort. Sci. 119:477-480.
Ito, K., H. Numaguehi, and M. Inosaka. 1985. Relation of non-structural carbohydrate concentration in autumn to wintering ability of several tropical grasses in Southern Kyushi. Proc. XV Intl. Grasslands Conf. 15:363-365.

Johnston, W.J. and R. Dickens. 1977. Cold tolerance evaluation of several centipedegrass selections. Agron. J. 69:100-103.

Larcher, W. 1995. Physiological plant ecology. $3^{\text {rd }}$ ed. Springer-Verlag, Berlin-Heidelberg.

Maier, F.P., S.N. Lang, and J.D. Fry. 1994a. Evaluation of an electrolyte technique to predict St. Augustinegrass freezing tolerance. HortScience 29:316-318.

Maier, F.P., S.N. Lang, and J.D. Fry. 1994b. Freezing tolerance of three St. Augustinegrass cultivars as affected by stolon carbohydrate and water content J. Amer. Soc. Hort. Sci. 119:473476.

McCarty, L.B., R.J. Black, and K.C. Ruppert. 1992. Florida lawn handbook. Univ. Florida Coop. Ext. Bul. SP 45.

Reeves, S.A. and G.G. McBee. 1972. Nutritional influences on cold hardiness of St. Augustinegrass (Stenotaphrum secundatum). Agron. J. 64:447-450.

Robbins, N.S. and D.M. Pharr. 1988. Effect of restricted root growth on carbohydrate metabolism and whole plant growth in Cucumis sativus L. Plant Physiol. 87:409-413.

Rogers, R.A., J.H. Dunn, and C.J. Nelson. 1975. Cold hardening and carbohydrate composition of 'Meyer' zoysia. Agron. J. 67:836-838.

SAS Institute. 1991. SAS user's guide. SAS Inst., Cary, N.C.

West, S.H. 1973. Carbohydrate metabolism and photosynthesis of tropical grasses subjected to low temperatures. Plant response to climatic factors. Proc. Uppsala Symp. Ecol. and Conservation. 5:165-168. 